used for our patients, may cure some boys. Diagnosis of residual disease in the testis by routine biopsy before completion of chemotherapy may permit detection of those boys who require this treatment and perhaps improve the overall outlook for boys with leukaemia.

We thank Dr A H Cameron and Dr J M Bouton for their help and advice in the management of these patients, and the paediatricians who referred them to us for treatment.

A $\mathrm{O}$ was in receipt of a Leukaemia Research Fund Oncology Training Fellowship.

\section{References}

1 Eden O B, Hardisty R M, Innes E M, Kay H E M, Peto J. Testicular disease in acute lymphoblastic leukaemia in childhood. Br Med J 1978; i : 334-8.

2 Hardisty R M, Kay H E M, Peto J. Effects of varying radiation schedule, cyclophosphamide treatment, and duration of treatment in acute lymphoblastic leukaemia.
Report to the Medical Research Council by the Working Party on Leukaemia in Childhood. Br Med J 1978; iii: 787-91.

3 Stoffel T J, Nesbit M E, Levitt S M. Extra medullary involvement of the testes in childhood leukemia. Cancer 1975 ; 35: 1203-11.

4 Kuo T T, Tschang T P, Chu J Y. Testicular relapse in childhood acute lymphocytic leukemia during bone marrow remission. Cancer 1976; 38: 2604-12.

5 Schaison G, Jacquillat Cl, Weil M, Auclerc M-F, Desprez Curely J-P, Bernard J. Reclucte à localisations gonadique au cours des leucémies aignës 113 cas. Nouv Presse Med 1977; 6: 1029-32.

6 Hustu H P, Aur R J A. Extramedullary leukaemia. Clin Haematol 1978; 7: 325-34.

7 Cornbleet M A, Chessells J M. Bone marrow relapse in acute lymphoblastic leukaemia in childhood. Br Med J 1978; ii: 104-6.

8 Atkinson K, Thomas P R M, Peckham M J, McElwain T J. Radiosensitivity of the acute leukaemic infiltrate. Eur $J$ Cancer 1976; 12: 535-40.

${ }^{9}$ Kearney P J, Baumer J H. Letter: Relapse in acute lymphoblastic leukaemia. Br Med J 1978; ii : 639-40.

Correspondence to Dr A Oakhill, Children's Hospital, Ladywood Middleway, Ladywood, Birmingham B16 8ET.

\title{
Decreased serum tuftsin concentrations in sickle cell disease
}

\author{
ZVI SPIRER, YOSEF WEISMAN, VERA ZAKUTH, MATI FRIDKIN, AND NAHUM BOGAIR \\ Division of Paediatrics, Governmental Municipal Medical Centre, Tel Aviv University Medical School, and \\ Department of Organic Chemistry, The Weizmann Institute of Science, Rehovot, Israel
}

SUMMARY The serum concentrations of the phagocytosis-stimulating peptide, tuftsin, were determined by radioimmunoassay in 21 patients with sickle cell disease and in 12 healthy controls. The mean serum tuftsin concentration was significantly lower in patients with haemoglobin SS disease $(154 \cdot 3 \pm 35 \cdot 1$ $\mathrm{ng} / \mathrm{ml} ; 308.6 \pm 70.2 \mathrm{nmol} / \mathrm{l}, \mathrm{P}<0.01)$ and in patients with haemoglobin SC and CC disease $(180 \cdot 9 \pm 42 \cdot 7 \mathrm{ng} / \mathrm{ml} ; 361 \cdot 8 \pm 85 \cdot 4 \mathrm{nmol} / 1$, $\mathrm{P}<0.05)$ than in healthy controls $(228.7 \pm 46 \cdot 7$ $\mathrm{ng} / \mathrm{ml} ; 457 \cdot 4 \pm 93 \cdot 4 \mathrm{nmol} / \mathrm{l})$. Tuftsin deficiency is an indicator of splenic hypofunction and may contribute to the increased susceptibility of patients with sickle cell disease to severe infection.

Najjar and his associates described a cytophylic gammaglobulin, leucokinin, that stimulates phagocytosis by polymorphonuclear leucocytes and macrophages. The full biological activity of leucokinin resides in a tetrapeptide (Thr-Lys-Pro-Arg) named tuftsin, which is covalently bound to the heavy chain of the gammaglobulin. ${ }^{1-2}$ It is believed that the spleen is actively involved in either the generation or the release, or both, of the peptide from its carrier heavy chain as serum tuftsin concentrations are very low after elective splenectomy, and in functional asplenia due to infiltrative disease or infarction of that organ..$^{3-5}$ Functional asplenia contributes to the increased susceptibility of patients with sickle cell disease (SCD) to severe infections. ${ }^{6}$ We have, therefore measured the serum tuftsin concentrations in patients with SCD and compared the values with those found in healthy controls.

\section{Patients and methods}

21 patients (14 with homozygous SS disease, 5 with haemoglobin SS disease, and 2 with haemoglobin CC disease) and 12 healthy age-matched controls were studied; the patients and controls were aged between 3 and 21 years. The patients were neither infected nor in crisis at the time or during the 6-month period preceding blood collection, and none of them had been transfused in the 6 months before the study. In 7 of the patients with haemoglobin SS disease, 
Howell-Jolly bodies were observed on peripheral blood smears. Consent was obtained from patients or parents; the sera were collected in St Petersburg, Florida, stored at $-20^{\circ} \mathrm{C}$, and shipped frozen to Israel for assay. Serum tuftsin was determined by radioimmunoassay as previously described. ${ }^{5}$

\section{Results}

The mean $( \pm \mathrm{SD})$ serum tuftsin concentration was significantly lower (Figure) in patients with haemoglobin SS disease $(154 \cdot 3 \pm 35 \cdot 1 \mathrm{ng} / \mathrm{ml}, \mathrm{P}<0 \cdot 01)$ and in patients with haemoglobin SC and haemoglobin CC disease $(180.9 \pm 42.7 \mathrm{ng} / \mathrm{ml}, \mathrm{P}<0.05)$ than in healthy controls $(228 \cdot 7 \pm 46 \cdot 7 \mathrm{ng} / \mathrm{ml})$. The mean $( \pm \mathrm{SD})$ serum tuftsin concentration in haemoglobin SS disease patients with Howell-Jolly bodies in their peripheral blood smears was $147 \pm 44 \cdot 3$ $\mathrm{ng} / \mathrm{ml}(294 \cdot 0 \pm 88 \cdot 6 \mathrm{nmol} / \mathrm{l})$.

\section{Discussion}

Overwhelming infections contribute significantly to

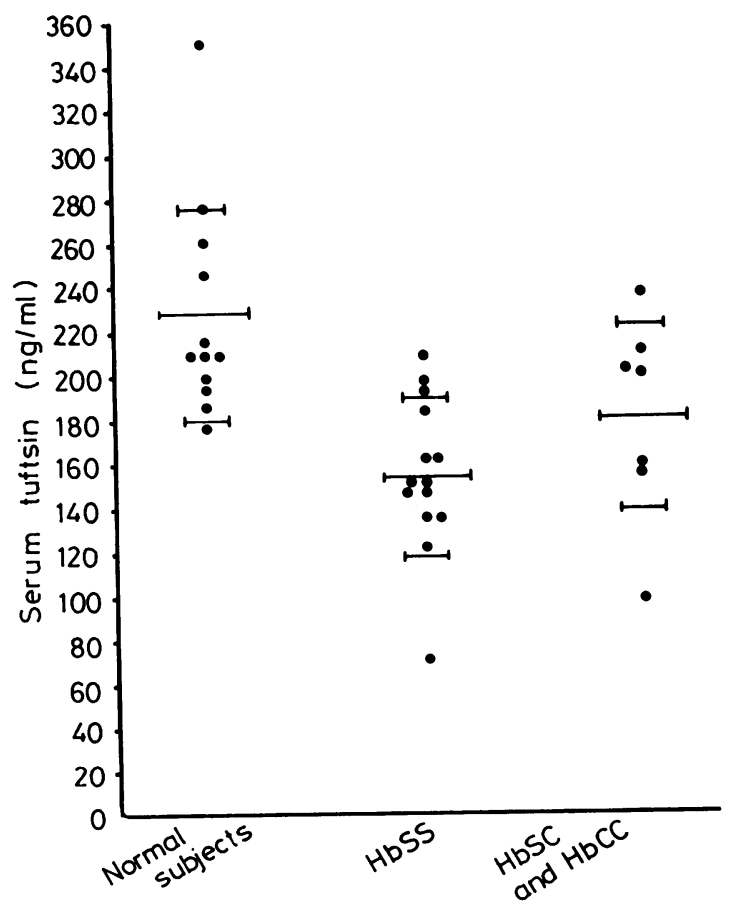

Figure Serum concentrations of tuftsin in patients with sickle cell disease and in normal controls (solid lines, mean $\pm S D$ ).

Conversion: traditional units to $S I-1 \mathrm{ng} / \mathrm{ml} \simeq 2 \cdot 0 \mathrm{nmol} / 1$. mortality and morbidity in patients with SCD. ${ }^{7}$ Although several abnormalities of host defence have been shown in SCD patients, ${ }^{7-8}$ functional and eventually anatomic asplenia is likely to be an important factor in the pathogenesis of the increased susceptibility of these patients to systemic infections. ${ }^{6-7}$ The present data indicate that measurement of serum tuftsin levels may well be of value as an indicator of the presence of a defective splenic function in SCD patients. Indeed, the lowest mean serum tuftsin concentration was recorded in patients with haemoglobin SS disease. In half of these patients, Howell-Jolly bodies, a reliable indicator of the presence of splenic hypofunction, ${ }^{6}$ were observed on peripheral blood smears. Our findings are in good agreement with those of Najjar who measured serum tuftsin activity in SCD patients using the polymorphonuclear leucocytes-bacteria phagocytosis system. ${ }^{4}$ Severe infections often occur in patients with familial tuftsin deficiency. ${ }^{14}$ It is likely, therefore, that tuftsin deficiency, in addition to its importance as an indicator of splenic hypofunction, impairs the phagocytic function of the blood polymorphonuclear leucocytes and of macrophages in SCD patients and contributes to the increased susceptibility of these patients to severe infections.

We thank Dr J Vidal, St Petersburg, Florida, for helping with the collection of blood samples.

\section{References}

1 Naijar V A. Molecular basis of familial and acquired phagocytosis deficiency involving the tetrapeptide Thre-Lys-Pro-Arg, tuftsin. Exp Cell Biol 1978; 46: 114-26.

2 Nishioka K, Constantopoulos A, Najjar V A. Characteristics and isolation of the phagocytosis stimulating peptide, tuftsin. Biochim Biophys Acta 1973; 310: 217-29.

3 Spirer Z, Zakuth V, Diamant S, et al. Decreased tuftsin concentrations in patients who have undergone splenectomy. $\mathrm{Br}$ Med J 1977; ii: 1574-6.

4 Najjar V A. Defective phagocytosis due to deficiencies involving the tetrapeptide, tuftsin. J Pediatr 1975; 87: $1121-4$.

5 Spirer Z, Zakuth V, Bogair N, Fridkin M. Radioimmunoassay of the phagocytosis-stimulating peptide, tuftsin, in normal and splenectomised subjects. Eur $J$ Immunol 1977; 7: 69-74.

- Pearson H A, Spencer R P, Cornelius E A. Functional asplenia in sickle cell anemia. $N$ Engl $J$ Med 1969; 281 : 923-6.

7 Johnston R B, Jr. Increased susceptibility to infection in sickle cell disease: review of its occurrence and possible causes. South Med J 1974; 6: 1342-8.

8 Winkelstein J A, Drachman R H. Deficiency of pneumococcal serum opsonizing activity in sickle cell disease. N Engl J Med 1968; 279 : 459-66.

Correspondence to Dr Z Spirer, Rokach Hospital, PO Box 51, Tel Aviv, Israel. 